CUAJ honors its members and friends who have passed away. We invite colleagues of the deceased to submit brief remembrances. Please limit your notice to 200 words. Send your notice to journal@cua.org or fax it to 514-395-1664.
Cite as: Can Urol Assoc J 2022;16(2):E1 12. http://dx.doi. org/10.5489/cuaj.7806

\section{Dr. Michael Allard}

It is with sadness that we learned that Dr. Michael Allard passed away January 15, 2022 in hospice care after a brief battle with an unknown primary cancer. This was not Mike's first experience with cancer. He survived testicular cancer at a much younger age that was treated by the late Dr. William (Bill) Lakey.

Mike was a native Edmontonian, born in 1943. He received his medical degree in 1968 from the University of Alberta ( $U$ of $A$ ) and then completed his military service, spending three years mostly in Germany. He made long-term friends while serving with the Canadian Forces.

Upon his return to Canada, he joined the $\mathrm{U}$ of $\mathrm{A}$ urology training program, then under the leadership of the late Dr. J.O. Metcalfe. He completed his training in 1976 and established a general urology practice in Edmonton at the Edmonton General Hospital, the Charles Camsell Hospital, the Royal Alexander Hospital, and the Misericordia Hospital. Mike provided a full scope of urological care; however, his area of interest was female urology. He attended many postgraduate courses in female urology and brought back to Edmonton several new technologies in dealing with female urinary incontinence. He shared urodynamic-related interests with the late Dr. Lawrence (Larry) Mix.

Mike participated in the training of residents and medical students at the $U$ of $A$. He was a very kind and patient mentor, while providing urological care to his patients. Many students and residents benefited from his guidance.

Eventually, Mike and his wife Mavis decided to move to Vancouver Island, where he continued to practice urology and share his expertise. He was well-respected by the medical communities of the Comox Valley and Campbell River.

Mike retired from clinical practice in 2015. After his retirement, he became involved passionately in photography. He had an artistic eye for composition and photographic technics, especially for wildlife. He was a member of the Comox Valley Photographic Society. He presented at several photography shows and many of his photos were well-known to enthusiasts. Mike had many other interests and talents. He loved the lake life and the mountains and spent as much time as possible at his beautiful family cottage on Lake Edith in Jasper Park. Mike loved to golf, downhill snow ski, and to canoe. He and his wife Mavis were gracious hosts and loved to share their cottage with their family and friends. Mike was an excellent chef and had a passion for good food and wines. Mike was adventurous and liked to travel. Above is a picture of him during a trip to Tanzania that captures his smile and joy of nature (credit Jamie Chartrand).

Mike leaves behind his adoring, supportive wife, two loving daughters, a grandson, and many friends, colleagues, and patients that were touched by this wonderful physician and human being.

He will be greatly missed but not forgotten, with so many great memories.

- Contributed by Dr. Guillermo Beristein 